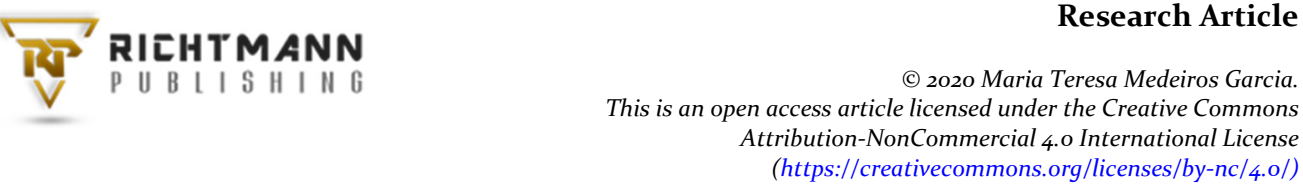

Received: 28 October 2019 / Revised: 11 December 2019 / Accepted: 24 December 2019 / Published: 10 January 2020

\title{
Individual Retirement Accounts in Portugal
}

\author{
Maria Teresa Medeiros Garcia' \\ ISEG, Lisbon School of Economics and Management, \\ Universidade de Lisboa, Rua Miguel Lupi, 20, 1249-078 Lisboa, Portugal
}

Doi: 10.36941/mjss-2020-0o10

Abstract

In Portugal, Individual Retirement Accounts (IRAs) were created with significant tax incentives in 1989. To inform the debate with research findings, the purpose of this paper is to analyze the determinants of IRAs' participation, both for retired and no-retired persons. The paper uses ASF (Portuguese Insurance and Pension Funds Supervisory Authority) Statistics and European Survey of Health, Ageing and Retirement in Europe (Share) database, Wave 4, and a probit model. The results show that the variables that have a positive and significant impact on the ownership of IRAs are age, years of education, income, and house ownership.

Keywords: Individual Retirement Account; SHARE; probit model; Portugal

\section{Introduction}

The objective of this paper is to analyse IRAs' participation determinants in Portugal contributing to the sparse literature on individual retirement saving decisions. Most of the studies are based on the U.S.A. and a comparable study has not been undertaken in Portugal. This study seeks to fill that void.

In Portugal, since the last two decades of the $20^{\text {th }}$ Century, personal saving rates have exhibited large declines, which are not unique in the European Union (EU) - 28 countries $^{2}$. Therefore, Portuguese governments have successively stimulated personal long-term saving, not only through the offering of tax incentives to savers, but also through the establishment of a legal framework for financial institutions that supply specific long-term saving products as Individual Retirement Accounts (IRAs 3 ) (Garcia, 2006). IRAs were created with tax incentives in many countries (Attanasio and Banks, 1998; World Bank, 1994, 2001). Governments believed that by exempting contributors from certain taxes, especially for IRAs, personal savings would increase more than the tax revenue loss. However, this expected effect might not happen. Based on the U.S.A. case, Skinner (1991) concluded that IRAs may not be as effective in increasing savings as expected. Indeed, the degree of adhesion for these accounts is relatively small and the real impact of tax incentives on aggregate saving increase is difficult to detect. In addition, it seems that most of the tax benefits have gone to

\footnotetext{
${ }^{1}$ UECE (Research Unit on Complexity and Economics is financially supported by FCT (Fundação para a Ciência e a Tecnologia), Portugal. This article is part of the Strategic Project (UID/ECO/oo436/2019). REM - Research in Economics and Mathematics.

${ }^{2}$ Although household saving rate in Portugal is lower than the correspondent in EU - 28 countries and Euro area - 19 countries, it is quite similar with Denmark, Ireland, Finland and UK (Eurostat).

3 In Portugal it is known as 'Planos Poupança-Reforma', or personal retirement savings plans.
} 
high-income households (Gale and Scholz, 1994; McCarthy and Pham, 1995; Skinner and Hubbard, 1996; Antolin et al., 2004). Venti and Wise (1987) present evidence, based on Consumer Expenditure Surveys (CESs), for the period 1980 through the first quarter of 1984, suggesting that the vast majority of IRA saving represents net new saving. Garcia and Marques (2017) examine the factors that influence the ownership of IRAs in eight European Union (EU) countries, suggesting that age, years of education, income, and house ownership have a positive and significant impact on household saving decision, whereas number of children, marital status, and risk aversion influence negatively that decision.

This paper analyses the enrolment pattern of IRAs in Portugal using Wave 4 (2010-2011) of the data of the European Survey of Health, Ageing and Retirement in Europe (SHARE) project (BörschSupan, 2013).

The paper is organized in six sections. The second section presents a brief framework of retirement saving plans in Portugal. A review of the literature of the determinants of retirement saving decisions including IRAs follows. Section four describes the sample used from the SHARE data base as well as the methodology. The results are presented on section five, and section six concludes.

\section{Framework}

Beginning with Portugal's entry preparation for the European Monetary Union, back in the middle 1980s, household saving rate started to register significant decreases (Figure 1). This saving rate is well below the EU average, attaining the lowest value of $6.81 \%$ by 2008 . The austerity programme after the Portuguese bail-out of 2011 might have contributed to the further decrease, which attained a minimum value of $4.19 \%$ in 2015 (BIS, 2011).

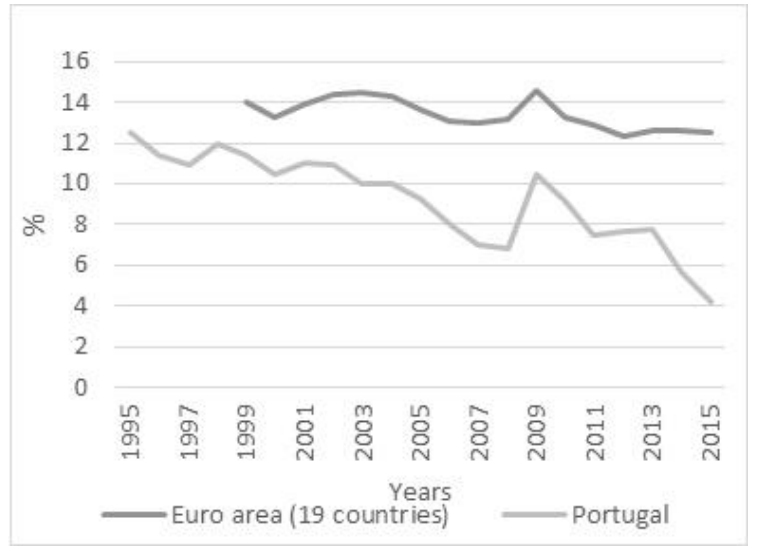

Fig. 1: Household Saving Rates, Portugal and the EU area, 1995-2015

Source: Eurostat

This context generated considerable concern among policymakers, which led to the establishment of IRAs by 1989. On balance, over the last decades, a number of legal documents have been produced to facilitate the participation in IRAs. An exempt-exempt-taxed (EET) system was adopted (Antolin et al., 2004), and sums can be converted into an annuity, or can be paid out as a lump-sum at retirement age, although some exceptions were considered.

Between 1994 and 2004 there was a significant positive trend in the number of retirement saving plans. During the subsequent decade, this number is more or less the same, being 24 in 2014 (Figure 2). 


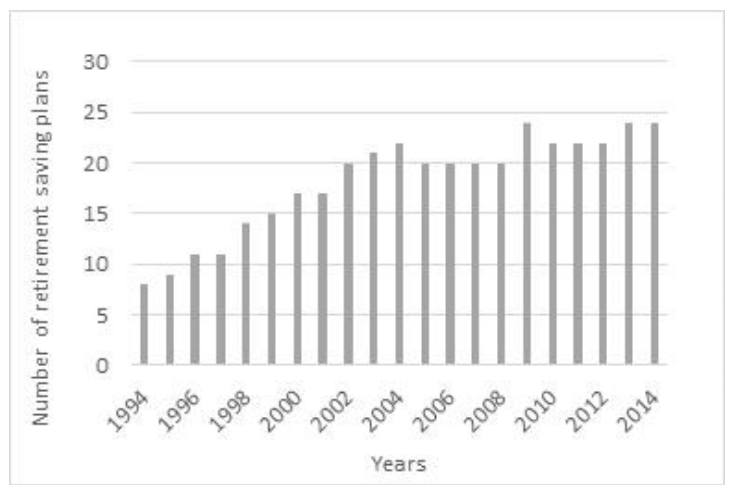

Fig. 2: Number of retirement saving plans in Portugal, 1994-2014

Source: ASF, Portuguese Insurance and Pension Funds Supervisory Authorit

The number of participants has been more or less stable after 1998, but after 2010 it registers a negative trend. In 2014, there are 63,251 participants, representing $1.2 \%$ of the active population (Figures 3 and 4), revealing a very low level of participation, as this is voluntary.

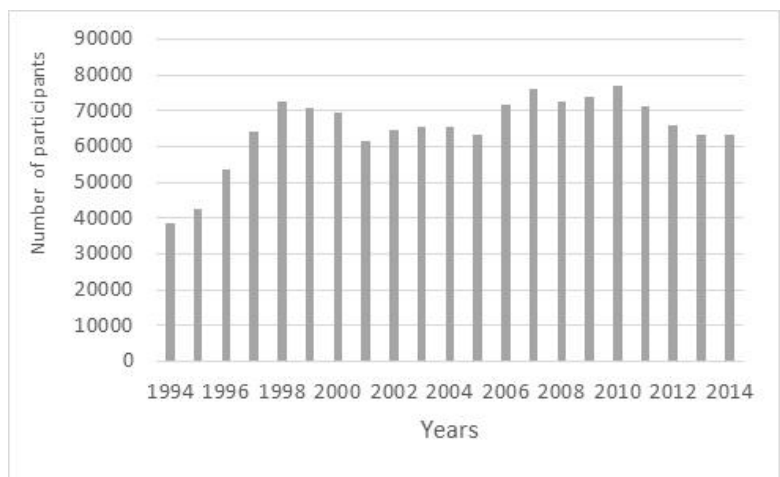

Fig. 3: Number of participants in retirement saving plans in Portugal, 1994-2014 Source: ASF, Portuguese Insurance and Pension Funds Supervisory Authority

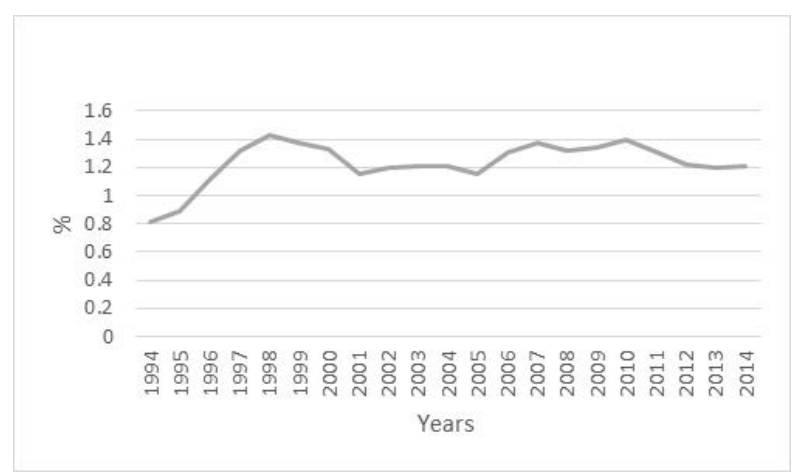

Fig. 4: Number of participants in retirement saving plans as a $\%$ of the active population in Portugal, 1994-2014

Source: ASF, Portuguese Insurance and Pension Funds Supervisory Authority 
The evolution of the amounts under management has been quite volatile, averaging around 400 million Euros (Figure 5).

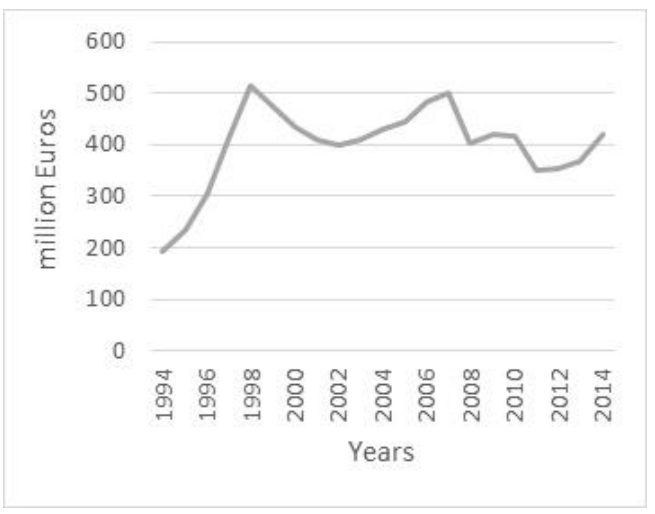

Fig. 5: Amounts under management of retirement saving plans in Portugal, 1994-2014 (million Euros) Source: ASF, Portuguese Insurance and Pension Funds Supervisory Authority

Finally, the performance in terms of rate of return shows increasing volatility since 2008 . The average rate of return is $2.45 \%$ between 1999 and 2014 (Figure 6). Indeed, the high degree of risk might be one of the factors that discourages people from enrolling in IRAs (Casey, 2004).

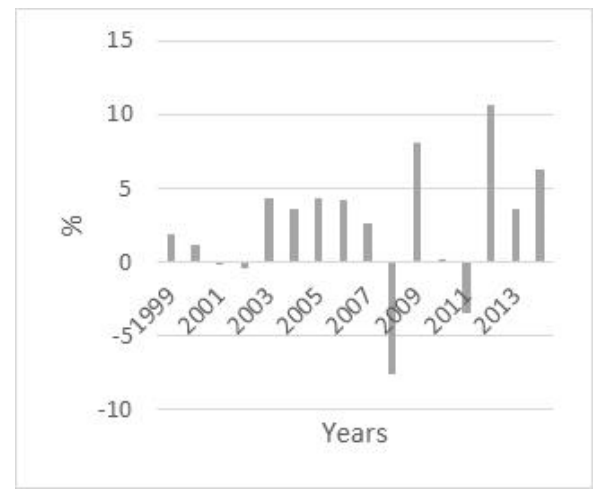

Fig. 6: Rate of return of retirement saving plans in Portugal, 1999-2014 (\%)

Source: ASF, Portuguese Insurance and Pension Funds Supervisory Authority

It seems that personal retirement saving plans not to have been an alternative to boost saving in Portugal. This is one of the reasons why studying the determinants of enrolling in IRAs is most important. The features of social security systems, as well as the existence, or not, of mandatory occupational pension schemes might have implications on the saving decision and also on the optimal amount of savings. Individuals who expect to receive a pension that replaces a high percentage of their net income (replacement rate), do not feel the same need for saving when compared with those who do not await for it (Garcia, 2009). Furthermore, the saving decision and the optimal amount of savings both depend on individual circumstances, such as age, income, education, etc.

However, frequently, individuals rely their retirement and saving decisions on herd behavior, faulty logic, or defective information (Garcia, 2009). Furthermore, a significant percentage shows an 
impressive lack of knowledge of the varibles determining future retirement incomes (Burtless, 2004). Therefore, greater attention should be put on education and regulation issues (Mitchell and Utkus, 2003).

\section{Literature Review}

Lusardi (2003) concluded that only a few people feel that they are able to plan effectively for retirement (EBRI, 2003). DeVaney and Chiremba (2005) found that several factors, such as having a better education, being more willing to accept risk, and enhancing past savings behavior are the most effective for retirement saving, when comparing the retirement savings of the baby boomers and other cohorts in the U.S.A. Behavioral economics provides a psychological explanation for the lack of retirement preparation, which is called "lack of willpower", or "bounded self-control". Therefore, individuals make attempts to save for retirement, but frequently prove to be limited in their ability to execute their plans (Thaler and Shefrin, 1981; Garcia, 2009), as occurs in several behavior modification courses, such as exercising, dieting, or quitting smoking. The acknowledgement of the existence of this limitation gives support to the use of commitment mechanisms that induce recommendable changes in behavior. For example, imposing withdrawal restrictions for IRAs can be a relevant device in helping to prevent lapses in personal willpower (Garcia, 2009; Butrica et al., 2010; Ghillarducci, 2010).

Investigation on the retirement saving decisions determinants consider both socio-economic characteristics and expectations and attitudes variables. The prominent features of IRA participants are age, wealth, and income, which means that an IRA participant is older, with higher income and with greater liquid wealth compared with non-participants individuals (Skinner, 1991). However, other explanatory variables may be included. This has been the case in research that uses well known databases: the U.S.A. Health and Retirement Study (HRS), the English Longitudinal Study of Ageing (ELSA), and the Survey of Health, Ageing and Retirement in Europe (SHARE). For example, Lundberg and Ward-Batts (200o) used the HRS to analyze the effect of the age difference between the couple on saving behavior, concluding that variables as age, health status, and education are significant determinants of net worth, but not the age difference. Clark et al. (2006) showed the relevance of educational events in retirement saving behavior. Furthermore, Fernandéz-López et al. (2010) concluded that age, financial literacy, income, and nationality are the principal determinants that influence saving behavior in some EU countries. In addition, Agarwal (2007) presents evidence that the importance of house ownership in saving decision by assessing the impact of house price misestimation on households' consumption and saving behaviors ex post.

Alessie et al. (2013) came to the conclusion that, as a result of pension reforms in Europe, households will have to increase private saving. On the other hand, Jappelli and Padula (2013) found that financial literacy and wealth are positively correlated over the life-cycle, and that early upgrade in mathematical skills will improve households' financial literacy, with a positive impact on their wealth accumulation.

Beckmann et al. (2013) analyzed household saving decisions between 2010 and 2011 in ten European countries. They concluded that employment, income, and education positive and significantly impact on households' savings, whereas number of younger children in household and number of teenage children are not significant variables. On the other hand, middle-aged people are more likely to save then younger and older people. Furthermore, risk averse people are more likely to save.

Rey-Ares et al. (2015) conducted an empirical analysis of data from SHARE to derive the potential driving factors of saving for retirement in Portugal and Spain, focusing only in the nonretired aged less than 65 years.

Garcia and Marques (2017) examined retirement saving decisions related to the ownership of IRAs in Austria, Denmark, France, Germany, Italy, Netherlands, Spain and Sweden. An empirical analysis of the factors that influence the ownership of IRAs is given, using data from both Wave 2 
(2006-2007) and Wave 4 (2010-2011) of SHARE. Further, they considered the impact of legal retirement age in the ownership of IRAs, through the inclusion of two subsamples: people aged between 50 and 64 years old (50-64 years) and people aged 65 or over ( $\geq 65$ years).

This country case study extends the literature because analyses the determinants of ownership of IRAs in Portugal using the SHARE database. The explanatory variables considered are based on the literature review, on the life-cycle theory (Deaton 2005), and also on the availability of data from SHARE. In addition, in order to detect specific determinants according to age, two subsamples were considered using the legal retirement age of 65 years old 4 to split the data.

\section{Data and Methodology}

The empirical analysis uses data from Wave 4 (2010-2011) of SHARE, as Portugal only joined the SHARE project at this stage. The survey initiated in 2004-2005, with Wave 1, and collects data about health, socio-economics, and social networks on people aged 50 or more in various regions in Europe. Subsequent waves included more countries and more information (Börsch-Supan, 2013).

The dependent variable used was Has Individual Retirement Accounts. The independent variables consider the factors that influence saving decisions mentioned in the literature review including: age, gender, education, marital status, presence of partner in household, household size, number of children, income, job situation, house ownership, and risk aversion. The definition of the variables and the expected impact on the ownership of IRAs is shown in Table 1.

Table 1: Definition of Variables

\begin{tabular}{|c|c|c|}
\hline Variables & Description & Expected effect \\
\hline \multicolumn{3}{|l|}{ Dependent } \\
\hline $\begin{array}{l}\text { Has individual retirement } \\
\text { accounts }\end{array}$ & Assumes value 1 if the respondent has a IRA; o otherwise & \\
\hline \multicolumn{3}{|l|}{ Independent } \\
\hline Age & Age of the respondent & $+/-$ \\
\hline Male & Assumes value 1 if the respondent is male; o otherwise & $+/-$ \\
\hline Years of education & Number of years of education of respondent & + \\
\hline Higher Education degree obtained & Assumes value 1 if the respondent has a high education degree; otherwise & $+/-$ \\
\hline Married & Assumes value 1 if the respondent is married; o otherwise & $+/-$ \\
\hline Partner in a household & Assumes value 1 if the respondent's partner is in a household; o otherwise & + \\
\hline Household size & Number of persons in household & + \\
\hline Number of children & Number of children in household & + \\
\hline Employed & Assumes value 1 if the respondent is employed; o otherwise & + \\
\hline Income & Income received in previous year & + \\
\hline Owns a house & Assumes value 1 if the respondent owns a house; o otherwise & + \\
\hline Risk aversion & $\begin{array}{l}\text { Attitude toward taking financial risks: } 1=\text { respondent isn't willing to take } \\
\text { any financial risks; o otherwise }\end{array}$ & + \\
\hline
\end{tabular}

The dependent variable was retrieved from the Assets module of SHARE and the independent variables were obtained from the Children, Coverscreen, Demographics, Employment and Pensions, Expectations, Household Income, and Housing modules of SHARE. The data file used in the analysis is the result of the merger of these modules.

In addition, the data file was split into two subsamples, people in working age and retired people, so that possible different significant determinants and influences of ownership of IRAs could be detected with age.

Table 2 displays the percentage of individuals with IRAs, by age range. Only $16 \%$ have IRAs. In addition, people in working age have a higher percentage of individuals with IRAs, when compared with retired people.

${ }^{4}$ Since 2013, legal retirement age changes with average life expectancy (Garcia, 2017). 
Table 2: Has Individual Retirement Accounts, Portugal

\begin{tabular}{l|c|c|c}
\hline Has individual retirement accounts & Total & People Aged between 50 and 64 & Population Aged 65 or Over \\
\hline Refusal & $0.75 \%$ & $0.35 \%$ & $1.05 \%$ \\
Don't know & $1.12 \%$ & $1.41 \%$ & $0.91 \%$ \\
No & $82.07 \%$ & $75.70 \%$ & $86.70 \%$ \\
Yes & $16.06 \%$ & $22.54 \%$ & $11.34 \%$ \\
\hline Total & 1,339 & 568 & 767 \\
\hline
\end{tabular}

Source: Wave 4, SHARE

Tables 3 and 4 show that that the majority of people surveyed answered that both partners have IRAs, and is male.

Table 3: Who has Individual Retirement Accounts, Portugal

\begin{tabular}{l|c|c|c}
\hline Who has individual retirement accounts & Total & People Aged between 50 and 64 & Population Aged 65 or Over \\
\hline Refusal & - & - & - \\
Don't know & $1.26 \%$ & $2.02 \%$ & - \\
Respondent only & $41.14 \%$ & $38.38 \%$ & $45.76 \%$ \\
Husband/wife/ partner only & $12.66 \%$ & $15.15 \%$ & $8.48 \%$ \\
Both & $44.94 \%$ & $44.44 \%$ & $45.76 \%$ \\
\hline Total & 158 & 99 & 59 \\
\hline
\end{tabular}

Source: Wave 4, SHARE

Table 4: Who has Individual Retirement Accounts, by Gender; Portugal

\begin{tabular}{l|c|c|c}
\hline Has individual retirement accounts & Total & People Aged between 50 and 64 & Population Aged 65 or Over \\
\hline Male & $53.49 \%$ & $51.56 \%$ & $43.68 \%$ \\
Female & $46.51 \%$ & $48.44 \%$ & $56.32 \%$ \\
\hline Total & 215 & 128 & 87 \\
\hline
\end{tabular}

Source: Wave 4, SHARE

We use a probit model to analyze the dependent variable, which is a binary variable (Wooldridge, 2009). The probit model is a statistical probability model with two categories in the dependent variable. In this case, the ownership of IRAs takes the value of 1 if the individual answered yes, and takes the value of o if the individual answered no. Therefore, the binary dependent variable, $y$, takes on the values of zero and one.

Probit analysis is based on the cumulative normal probability distribution and, in this case, provides statistically significant findings of which factors increase or decrease the probability of ownership. The relationship between a specific variable and the outcome of the probability is interpreted by means of the marginal effect, which accounts for the partial change in the probability. Therefore, interest lies primarily in the response probability $P(y=1 \mid X)=P\left(Y=1 \mid x_{1}, x_{2}, \ldots, x_{k}\right)$, where $\mathrm{X}$ denotes the full set of independent variables, containing various socioeconomic and demographic characteristics: age, gender, education, marital status, presence of partner in household, household size, number of children, income ${ }^{5}$, job situation, house ownership, and risk aversion.

A probit model can be obtained from an underlying latent variable model constituted by:

$y^{*}=\alpha+\sum X \beta+\varepsilon, \varepsilon \sim N(0,1)$,

${ }^{5}$ The variable considered for income represents the total income received in the previous year, 2009. 
where $y^{*}$ is the unobserved continuous variable that causes the value of $\mathrm{y}, \alpha$ the constant, $X$ the vector of the independent variables, $\beta$ the parameters, and $\varepsilon$ the random disturbance term. The value of $y$ is obtained as $y=\left\{\begin{array}{c}1 \text { if } y^{*}>0 \\ 0 \text { otherwise }\end{array}\right\}$.

The model was estimated using data from Portugal, which is an unbalanced data set and STATA 12.

Three versions of the model were estimated, according to the age criterion data split. First, it was applied to the total sample (with 1,247 observations - Model 1). Secondly, the estimation used the subsample of people aged between 50 and 64 years old (with 531 observations - Model 2), and the subsample of people aged 65 or over (with 716 observations - Model 3 ).

\section{Results}

Table 5 (Models 1, 2 and 3 ) shows the results. The variables that show a positive and significant effect on the ownership of IRAs are: age, years of education, income and house ownership. Differently, risk averse people are unlikely to have IRAs and the variable number of children revealed a negative significant impact on the ownership of IRAs.

The variables age and number of children lose statistical significance when we consider the younger population, while income coefficient increases positive significance at $1 \%$ level. Yet, when the older population is considered, income and house ownership lose all significance whereas age diminishes levels of significance.

The results highlight the factors that determine participation in personal retirement saving plans, in a context of both declining household saving rates and pension reforms that reduce the pension promise and exalt prominent role to individuals (OECD, 2013; Garcia, 2017). This is an important contribution to policymakers, which is aligned with previous empirical evidence. The representative individual that participates in an IRA is one who is older, with more years of education, with a higher income and with more liquid wealth than the rest of population. This result might put to the question the role of personal plans in supplementing retirement provision and security in the case of less-educated individuals, with a lower income.

Table 5: Marginal Effects from Probit Regression

\begin{tabular}{|c|c|c|c|}
\hline & Model 1 & Model 2 & Model 3 \\
\hline Wave & 4 & 4 & 4 \\
\hline Age & all & $50-65$ & $>65$ \\
\hline Age & $\begin{array}{c}0.017^{* * *} \\
(0.005)\end{array}$ & $\begin{array}{c}0.007 \\
(0.018)\end{array}$ & $\begin{array}{l}0.017^{*} \\
(0.009)\end{array}$ \\
\hline Male & $\begin{array}{c}0.040 \\
(0.095)\end{array}$ & $\begin{array}{c}0.038 \\
(0.135)\end{array}$ & $\begin{array}{l}0.056 \\
(0.141)\end{array}$ \\
\hline Years of Education & $\begin{array}{c}0.066^{* * *} \\
(0.009)\end{array}$ & $\begin{array}{c}0.084^{* * *} \\
(0.015)\end{array}$ & $\begin{array}{c}0.056^{* * *} \\
(0.014)\end{array}$ \\
\hline Higher Education & $\begin{array}{c}0.002 \\
(0.002)\end{array}$ & $\begin{array}{c}-0.002 \\
(0.005)\end{array}$ & $\begin{array}{c}0.003 \\
(0.002)\end{array}$ \\
\hline Married & $\begin{array}{c}-0.170 \\
(0.179)\end{array}$ & $\begin{array}{c}-0.179 \\
(0.222)\end{array}$ & $\begin{array}{l}-0.083 \\
(0.339)\end{array}$ \\
\hline Partner in a household & $\begin{array}{c}0.179 \\
(0.187)\end{array}$ & $\begin{array}{c}0.211 \\
(0.233)\end{array}$ & $\begin{array}{c}0.104 \\
(0.347)\end{array}$ \\
\hline Household Size & $\begin{array}{c}0.045 \\
(0.042)\end{array}$ & $\begin{array}{c}-0.010 \\
(0.059)\end{array}$ & $\begin{array}{c}0.084 \\
(0.064)\end{array}$ \\
\hline Number of Children & $\begin{array}{c}-0.117^{* * *} \\
(0.038)\end{array}$ & $\begin{array}{c}-0.021 \\
(0.059)\end{array}$ & $\begin{array}{c}-0.177^{* * *} \\
(0.051)\end{array}$ \\
\hline Employed & $\begin{array}{c}-0.005 \\
(0.004)\end{array}$ & $\begin{array}{c}-0.009 \\
(0.006)\end{array}$ & $\begin{array}{c}-0.001 \\
(0.006)\end{array}$ \\
\hline Income & $0.368^{* *}$ & $0.669^{* * *}$ & 0.011 \\
\hline
\end{tabular}




\begin{tabular}{lccc}
\hline & Model 1 & Model 2 & Model 3 \\
\hline Wave & 4 & 4 & 4 \\
\hline & $(0.149)$ & $(0.199)$ & $(0.239)$ \\
Own House & $0.249^{* *}$ & $0.323^{* *}$ & 0.185 \\
& $(0.108)$ & $(0.161)$ & $(0.149)$ \\
Risk Aversion & $-0.745^{* * *}$ & $-0.687^{* * *}$ & $-0.792^{* * *}$ \\
& $(0.132)$ & $(0.200)$ & $(0.178)$ \\
\hline Number of observations & 1,247 & 531 & 716 \\
Correctly Predicted & $82.68 \%$ & $77.40 \%$ & $87.01 \%$ \\
Log Likelihood & -511.013 & -255.993 & -247.489 \\
Pseudo R & 0.136 & 0.144 & 0.111 \\
LR $\chi^{2}(12)$ & 161.30 & 85.76 & 61.81 \\
\hline
\end{tabular}

The standard errors are in parentheses. ${ }^{*}$ : significant at the $10 \%$ level; **: significant at the $5 \%$ level; ***: significant at the $1 \%$ level.

\section{Conclusion}

This study uses Wave 4 of SHARE data to analyze the variables that influence IRAs' participation in Portugal. We adopted the probit model and used a unique sample, which was split according to age.

The main factors that influence the dependent variable are: age; years of education; and income. Policy makers should, therefore, focus on this result if IRAs are considered to be an important method for boosting saving. This suggests that concerns with accumulating assets through this specific long-term saving product are specific to few people. Indeed, just a minority seems to be able to plan effectively for retirement putting in question the objective of IRAs of reinforcing retirement security, as the public pension system reforms raise major risks for future pension provision and adequacy. Policy makers should consider the individual characteristics that influence the enrolment in IRAs when addressing pension reform. Less-educated and lower income individuals seem not to be in conditions to rely on IRAs to supplement decreasing public retirement provision.

Spurring individual choice in the context of retirement security implicitly assumes that the individual to whom the responsibility of decision has been handed to is a well-informed economic agent, acting rationally to maximize their self-interest, meaning that he is able to participate in IRAs (Garcia, 2014). However, in the real world, individuals' decisions are subject to several restrictions, namely: bounded self-interest or bounded selfishness, meaning that individuals maximize their personal welfare, but they show to be far more cooperative and altruistic than economic theory expects they will be; bounded self-control, meaning that individuals have the right intentions or beliefs, but their insufficient determination limits the adequate changes in behavior; and bounded rationality, meaning that certain types of problems and decisions may be too complicated for individuals to understand and solve on their own (Banks and Oldfield, 2007; Garcia, 2009). These constraints are very important for the design, management, and regulation of personal retirement savings plans. Policy makers should become aware of the problems surrounding saving and financial decisions and take actions toward consumer protection regulation and financial literacy education (Garcia, 2006).

The maturing of personal retirement saving plans in Portugal must address the problem of individuals' inability to understand investment products, assuming that they have enough income. However, embracing financial literacy education might be both harmful as well as irrelevant. For some consumers, financial education might increase confidence without improving ability, leading to worse decisions (Williams, 2007; Arthur, 2012). For others, financial education will contribute to have responsible market players, much more aware of complex products in a volatile market and its impact on their retirement incomes (Garcia, 2006; Willis, 2008). Indeed, the efficacy of financial literacy education requires empirical support which emphasizes the need of policies more conducive to good consumer financial outcomes. 


\section{Acknowledgements}

This paper uses data from SHARE wave 4 release 1.1.1, as of March 28th 2013 or SHARE wave 1 and 2 release 2.6.0, as of November 29th 2013 or SHARELIFE release 1, as of November 24th 2010. The SHARE data collection has been primarily funded by the European Commission through the $5^{\text {th }}$ Framework Programme (project QLK6-CT-2001-0036o in the thematic programme Quality of Life), through the 6th Framework Programme (projects SHARE-I3, RII-CT-20o6-o62193, COMPARE, CIT5CT-2005-028857, and SHARELIFE, CIT4-CT-2006-028812) and through the 7th Framework Programme (SHARE-PREP, $\mathrm{N}^{\circ}$ 211909, SHARE-LEAP, $\mathrm{N}^{\circ} 227822$ and SHARE $\mathrm{M}_{4}, \mathrm{~N}^{\circ}$ 261982). Additional funding from the U.S. National Institute on Aging (Uo1 AGo9740-13S2, Po1 AGoo5842, Po1 AGo8291, P30 AG12815, R21 AGo25169, Y1-AG-4553-01, IAG BSRo6-11 and OGHA 04-064) and the German Ministry of Education and Research as well as from various national sources is gratefully acknowledged (see www.share-project.org for a full list of funding institutions).

\section{References}

Agarwal, S. (2007). The impact of homeowners' housing wealth mis-estimation on consumption and saving decisions. Real Estate Economics, 35(2): 135-154.

Alessie, R., Angelini, V., \& Van Santen, P. (2013). Pension wealth and household savings in Europe: Evidence from SHARELIFE. European Economic Review, 63: 308-328.

Antolin, P., de Serres, A., \& de la Maisonneuve, C. (2004). Long-Term Budgetary Implications of Tax-Favored Retirement Savings Plans. OECD Economic Studies, 2(39).

Attanasio, O. \& Banks, J. (1998) Trends in household saving don't justify tax incentives to boost saving. Economic Policy, 548-583. DOI: http://dx.doi.org/10.1111/1468-0327.00040.

Arthur, C. (2012). Financial Literacy Education: Neoliberalism, the Consumer and the Citizen, Educational Futures Rethinking Theory and Practice, Volume 53, Sense Publishers, Rotterdam, The Netherlands.

Banks, J. \& Oldfield, Z. (2007). Understanding Pensions: Cognitive Function, Numerical Ability and Retirement Saving. Fiscal Studies, vol. 28, no. 2: 143-170.

Beckmann, E., Hake, M., \& Urvova, J. (2013). Determinants of Households' Savings in Central, Eastern and Southeastern Europe. Focus on European Economic Integration Q3/13.

BIS (2011). The impact of sovereign credit risk on bank funding conditions. CGFS Papers, No 43, Committee on the Global Financial System, July, Bank for International Settlements.

Börsch-Supan, A. (2013). Survey of Health, Ageing and Retirement in Europe (SHARE) Wave 1. Release version: 2.6.o. SHARE-ERIC. Data set. DOI: 10.6103/SHARE.w1.26o

Burtless, G. (2004). Social Norms, Rules of Thumb, and Retirement: Evidence for Rationality in Retirement Planning. The Brookings Institution, October.

Butrica, Barbara A., Smith, Karen E. \& Toder, Eric J. (2010). What the 2008 Stock Market Crash Means for Retirement Security. Journal of Aging E Social Policy, Volume 22, 2010 - Issue 4, 339-359.

Casey, H. B. (2004). Why People Don't Choose Private Pensions: The Impact of 'Contagion'. Discussion Paper PI0503, The Pensions Institute, UK.

Casey, B. H. (2014). From pension funds to piggy banks: (Perverse) consequences of the Stability and Growth Pact since the crisis. International Social Security Review, 67: 27-48. doi: 10.1111/issr.12029.

Clark, R. L., d'Ambrosio, M. B., McDermed, A. A., \& Sawant. K. (2006). Retirement plans and saving decisions: the role of information and education. Journal of Pension Economics and Finance, 5( o1): 45-67.

Deaton, A. S. (2005). Franco Modigliani and the Life Cycle Theory of Consumption. Presented at the Convegno Internazionale Franco Modgliani, Accademia Nazionale dei Lincei, Rome, February 17th-18th, 2005.

Devaney, S., Anong, S., \& Whirl, S. (2007). Household Savings Motives. Journal of Consumer Affairs, 41(1), $174-186$.

DeVaney, Sharon A. \& Chiremba, Sophia (2005). Comparing the Retirement Savings of the Baby Boomers and Other Cohorts. U.S. Department of Labor, Bureau of Labor Statistics.

Duflo, E. \& Saez, E. (2003). Implications of information and social interactions for retirement saving decisions. Pension Research Council Working Paper 2003-13, Philadelphia.

Employee Benefit Research Institute (EBRI) (2003). Retirement Confidence Survey: A Summary of Results.

Fernandéz-López, S., Milagros, L. O., \& Vivel, D. R. (2010). What Are the Driving Forces of Individuals' Retirement Savings?. Czech Journal of Economics and Finance, 6o(3): 226-251.

Gale, W. \& Scholz, J. K. (1994). IRAs and Household Saving. American Economic Review, 84(5): 1233-126o. 
Garcia, M. T. M. (2017). Overview of the Portuguese Three Pillar Pension System. International Advances in Economic Research, 23: 175-189. Published online: 21 April 2017. DOI 10.1007/s11294-017-9636-x

Garcia, M. T. M. (2009). Pension Reform and Individual Responsibility presented at the 7 th International Workshop on Pension, Insurance and Saving 28-29 Mai, 2009, Paris (http://international-pensionworkshop.com/past-events/7th-workshop/).

Garcia, M. T. M. (2006). Individual responsibility for the adequacy of retirement income. Pensions: An International Journal, Volume 11, Issue 3, 192-199. https://doi.org/10.1057/palgrave.pm.5940022

Garcia, M. T. M. (2014). Management of Pension Funds: the Case of Portugal. International Journal of Latest Trends in Finance and Economic Sciences, Vol 4, No 4, December, 792-802..

Garcia, M. T. M. \& Marques, P. (2017). Ownership of individual retirement accounts - an empirical analysis based on SHARE. International Review of Applied Economics, Volume 31, Issue 1, Pages 69-82. DOI: 10.1080/o2692171.2016.1221389

Ghilarducci, T. (2010). How to Supplement Social Security Fairly and Effectively.

Journal of Aging \& Social Policy, Volume 22, 2010 - Issue 2: Retirement Security in the Great Recession, 222-235.

Jappelli, T., \& Padula, M. (2013). Investment in financial literacy and saving decisions. Journal of Banking $\mathcal{E}$ Finance, 37(8): 2779-2792.

Lundberg, S. \& Ward-Batts, J. (200o). Saving for retirement: Household bargaining and household net worth. Claremont McKenna College Robert Day School of Economics and Finance Research Paper no. 2004-03.

Lusardi, A. (2003). Saving and the Effectiveness of Financial Education, in Money Matters: Shaping Retirement Decision Making. Edited by Olivia S. Mitchell and Stephen P. Utkus. Oxford University Press.

McCarthy, J. \& Pham, H. N. (1995). The Impact of Individual Retirement Accounts on Savings. Current Issues in Economics and Finance, September Vol.1 Number 6, FRBNY.

Mitchell, O. S. \& Utkus, S. P. (2003). Lessons from Behavioral Finance for Retirement Plan Design. Pension Research Council WP.

OECD (2013). Pensions at a Glance 2013: OECD and G2O Indicators. OECD Publishing. http://dx.doi.org/10.1787/pension_glance-2013-en.

Rey-Ares, L., Fernández-López, S., \& Vivel-Búa, M. (2015). The determinants of privately saving for retirement: the cases of Portugal and Spain. European Journal of Applied Business and Management, 1(1).

Skinner, J. (1991). Individual Retirement Accounts: A Review of the Evidence. NBER, WP 3938.

Skinner, J. \& Hubbard, R.G. (1996). Assessing the Effectiveness of Saving Incentives. Journal of Economic Perspectives, 10(4), 73-90.

Thaler, R. \& Shefrin, H. M. (1981). An Economic Theory of Self-Control. Journal of Political Economy 89, 392-406.

Venti, S. F. \& Wise, D. A. (1987). Have IRAs Increased U.S. Saving?: Evidence from Consumer Expenditure Surveys. NBER Working Paper No. 2217, National Bureau of Economic Research, 1050 Massachusetts Avenue, Cambridge, MA 02138, April 1987.

Williams, T. (2007). Empowerment of Whom and for What? Financial Literacy Education and the New Regulation of Consumer Financial Services. Law and Policy, 29 (2). pp. 226-256. ISSN 1467-9930.

Willis, L. E. (2008). Against Financial Literacy Education. Iowa Law Review, Vol. 94, 2008; U of Penn Law School, Public Law Research Paper No. 08-10; Loyola-LA Legal Studies Paper No. 2008-13. Available at SSRN: https://ssrn.com/abstract $=1105384$

Wooldridge, J. M. (2009). Introductory econometrics: A modern approach, 4th edition. South-Western, Cengage Learning.

World Bank Policy Research Report (1994). Averting the Old Age Crisis, Policies to Protect the Old and Promote Growth, Oxford University Press.

World Bank (2001). New Ideas about Old Age Security, Holzmann, R. and Stiglitiz, J. E. (Editors). 